\title{
Identification of Morphometry and Carcass Composition of Local Sheep at Different Growth Rate
}

\author{
M. Yamin*, S. Rahayu, Komariah, M. Iswahyudi, \& R. Rachman \\ Department of Animal Production and Technology \\ Faculty of Animal Science, Bogor Agricultural University (IPB) \\ Jln Agatis, Kampus Darmaga, Bogor 16680, Indonesia \\ (Received 28-10-2011; accepted 20-03-2012)
}

\begin{abstract}
ABSTRAK
Usaha penggemukan domba semakin berkembang untuk memenuhi permintaan konsumen terhadap daging domba berkualitas. Namun demikian, bakalan domba muda yang akan digemukkan semakin hari semakin menurun kualitasnya dan sulit diperoleh. Kombinasi usaha penggemukan dan pembibitan domba harus dikembangkan secara proporsional agar usaha domba tersebut berjalan secara berkelanjutan. Dua belas ekor domba lokal muda jantan hasil seleksi dari populasi domba berdasarkan pertambahan bobot badan harian dibagi menjadi dua kelompok yaitu domba tumbuh cepat (TC) dan domba tumbuh lambat (TL). Beberapa ukuran morfometrik bagian tubuh dan kepala serta produksi dan komposisi karkas diukur dan dibandingkan pada dua kelompok domba tersebut. Hasil penelitian menunjukkan bahwa parameter morfometrik berupa lingkar dada, panjang badan, tinggi badan, panjang kepala, lingkar moncong, leher atas dan leher bawah, nyata lebih tinggi pada domba TC daripada domba TL $(P<0.05)$. Parameter tersebut dapat dijadikan indikator seleksi untuk pertumbuhan domba. Domba TC dan TL menghasilkan produksi dan komposisi karkas yang tidak berbeda nyata. Kesimpulan studi ini adalah seleksi domba untuk sifat kecepatan pertumbuhan melalui beberapa ukuran morfometrik domba dapat direkomendasikan. Seleksi tersebut tidak berdampak negatif terhadap berat dan persentase serta komposisi karkas yang dihasilkan.
\end{abstract}

Kata kunci: seleksi, domba lokal, pertumbuhan, morfometri, produksi karkas

\section{ABSTRACT}

Sheep fattening farms have been recently growing rapidly to produce better quality of sheep meat and fullfill consumer's demand. Sheep fattening and breeding farms should be developed proportionally to obtain sustainable sheep flock in the market. Twelve male lambs (less than one year old) were selected based on their average daily gain (ADG), consisting into two groups: 6 fast growing (FG) and 6 slow growing (SG) sheep. Some morphometric parameters in body and head parts of sheep and their carcass production and composition were measured and compared between the groups. The results show that chest circumference, body height, body length, head length and muzzle, top and bottom neck circumferences of FG sheep were significantly higher than in SG sheep $(\mathrm{P}<0.05)$. This may indicate that the parameters can be used as sheep selection criteria for growth rate. For carcass study, FG and SG sheep groups produced similar carcass weight and percentage as well carcass composition including meat, bone and fat in weight and percentages $(\mathrm{P}>0.05)$. It is concluded that selection of fast growing sheep can be recommended by using some morphometric parameters. The selection would not also negatively affect the weight and percentage of carcass composition.

Key words: selection, local sheep, growth, morphometry, carcass production

\section{INTRODUCTION}

At present, sheep commodity has been becoming an interesting agribusiness, especially in sheep fattening

\footnotetext{
* Corresponding author:

Telp/Fax. 0251-8628379; e-mail: mohamadyamin@yahoo.com
}

business which has been recently growing rapidly to produce better quality of sheep meat and fulfil consumer's demand. Sheep fattening program is a management system to raise lambs intensively by using good environment, including very good quality of feed, for period of time, to produce high growth rate and good quality of carcass and meat of sheep. However there are still variations of sheep growth rate that can make uncertain 
condition for the farmers, in which they can loose profit when they get the poor quality of sheep. Ironically, when the farmers can get good quality of growth rate, it can cause of a loss of genetic resource, due to the best sheep are sold and slaughtered. Sheep fattening and breeding commercial farms should be developed proportionally to achieve sustainability in the sheep business.

The large variation of growth performance of local sheep commonly occurs and this might relate to the genetic variation of the sheep are also high, due to breed quality is not pure yet genetically. This phenomenon is shown by Sumantri et al. (2008) that heterozygote value indicating genetic variation of local sheep was still high (it was 0,722 for Jonggol sheep and 0.649 for the average of local sheep), as a result of migration, mutation and crossbreeding. Sheep farm at Jonggol Animal Science Teaching and Research Unit (JASTRU), Bogor can become a model representing the genetic variation of sheep growth performance through their body weight. The local sheep at the farm have well adapted with the pasture management system, relatively hot and humid condition as well as with limited feed supply especially during summer. Body size and growth of similar age of sheep varied among the flock, it is therefore selection of sheep having fast growth need to be applied to improve sheep production. However growth is difficult to measure, therefore practical selection criteria to find fast growing sheep need to investigate. Certain body parameters (morphometry tubuh) also need to explore between the sheep groups, as well as to study their correlations with the growth rate. For the case of small size of sheep, it is also interesting to study whether they are surely useless when fattening technology would be applied. Comparative study of carcass composition between FG and SG sheep would be useful to study effect of selection on the parameters would not negative. These questions need to be answered to consider an appropriate sheep selection program to further develop a balance sheep fattening agribusiness.

The objectives of the research were to (i) compare some morphometric parameters between fast and slow growing sheep (ii) calculate the correlations between the parameters to determine selection criteria (iii) compare carcass composition between the groups of sheep.

\section{MATERIALS AND METHODS}

\section{Location and Time}

This experiment was conducted at Jonggol Animal Science Teaching and Research Unit (JASTRU), Faculty of Animal Science, Bogor Agricultural University, Singasari village, Jonggol District, Bogor. The farm is located about $75 \mathrm{~km}$ from Bogor between 106.53 EL and 06.53 SL with latitude of $145 \mathrm{~m}$ above sea, with average temperature and humidity are $30.4{ }^{\circ} \mathrm{C}$ and $79 \%$, respectively.

\section{Experimental Sheep}

Fifty heads of local thin tailed sheep were used (ram lambs, aged between 4-6 mo old) from JASTRU. They were raised extensively on the pasture during the day and in the sheep barn in the night. The sheep were measured their daily gain for $6 \mathrm{wk}$ and chosen into groups having daily gain more than $100 \mathrm{~g} / \mathrm{head} / \mathrm{d}$ and the one having less than $50 \mathrm{~g} / \mathrm{head} / \mathrm{d}$ and. This selection obtained 19 heads of sheep which were then raised in a short fattening program, for 1 mo with better feed quality by using supplementation of complete feed of $110 \mathrm{~g} / \mathrm{head} / \mathrm{d}$, given in individual pen in the morning then were grazed in special paddock for the experiment animals only. The feeding management was designed to give similar opportunity for sheep to get similar quality of nutrients (Nutrient composition is shown in Table 1). The sheep were weighed every week to measure daily gain. It was then selected the sheep into two groups: (i) the six fast growing sheep (FG) and the six slow growing sheep (SG) with the average daily gain of $140.15 \pm 36.41$ and $64.98 \pm 21.13 \mathrm{~g} / \mathrm{head} / \mathrm{d}$, respectively for FG and SG. The average daily gain for the population (19 heads) was $70 \mathrm{~g} / \mathrm{head} / \mathrm{d}$. Average body weight between FG and SG groups of sheep were $21.92 \pm 3.07$ and $16.17 \pm 2.48 \mathrm{~kg}$, respectively. It is therefore the two groups of sheep can be considered as different sheep groups having different growth rate (FG versus SG) as the treatment in this experiment.

The total 12 sheep were used to study morphometric measurements to find selection criteria. From these samples, based on the highest and the lowest daily gain groups, 3 lambs for each group were used for carcass study. The selection method for experimental sheep was based on modification of general principle in animal selection method for genetic improvements (Noor, 2008).

\section{Traits Measurement}

Parameters observed in this experiment were body weight, daily gain, some morphometrics and carcass production of the sheep. The morphometric parameters included in the body (chest circumference, body length, height, chest width), head and neck area (head length, muzzle, upper neck and bottom neck circumferences as well as neck length), and tail areas (tail length).

The methods of measurements of each parameter are as follows: (i) body weight is the weight of sheep at certain time of measurements, (ii) average daily gain is the average of weekly sheep weight gain for

Table 1. Nutrient composition of experiment feed (\%)

\begin{tabular}{lcccccc}
\hline Feed & Dry matter & Ash & Protein & Fibre & Fat & Beta-N \\
\hline Brachiaria humidicola Grass & 31.60 & 2.29 & 2.65 & 13.08 & 0.07 & 13.51 \\
Commercial complete feed & 70.43 & 18.80 & 8.09 & 15.78 & 2.74 & 25.02 \\
\hline
\end{tabular}


period of observation converted into day unit, (iii) chest circumference (heart girth) is the circle distance of chest measured behind forearms, (iv) body height is measured vertically from the thoracic vertebrae to the flat ground, ( $\mathrm{v}$ ) body length is the distance between shoulder point to tuber Ischia, (vi) chest depth is the distance between the highest point of top shoulder and bottom shoulder behind forearms, (vii) head length is the distance between muzzle and forehead, (viii) muzzle circumference is circumference distance of forehead and chin at front part of eyes, (ix) top neck circumference is circumference distance along the top neck, $(x)$ bottom neck circumference: circumference distance along the bottom neck, (xi) neck length is the distance between the top and bottom neck, and (xii) tail length is the: distance between the tail base to its end.

For studying carcass production the sheep were killed and prior to the slaughtering, sheep were fasting for 16 hours to minimize the digestion in evisceration tracts. Sheep were weighted first to know the slaughtering weight. Sheep were slaughtered at atlas bones cutting jugular vein, esophagus, and trachea. Methods of carcass preparation and measurement were adopted from Romans \& Ziegler (1977). Carcass weight is slaughtering weight that was minus blood, head, four legs, skin, stomach content, breast contents (heart, liver, lungs etc), and tail. Meat, bone and fat weight were the weight of the organs after being trimmed from carcass.

\section{Data Analysis}

Analysis of differences between treatments. Data of morphometric and carcass studies in two groups of sheep were analysed by using T-test, with formula of:

$\mathrm{t}=\frac{\overline{\mathrm{d}}-\mu_{\mathrm{d}}}{\frac{s_{d}}{\sqrt{n}}}$ or if $\mu_{\mathrm{d}}=0$, then $\mathrm{t}=\frac{\overline{\mathrm{d}}}{\frac{s_{d}}{\sqrt{n}}}$ freedom $(\mathrm{df})=\mathrm{n}-1$

Note :

$\mathrm{d}=$ difference between each individual or paired object. $\mu_{d}=$ Mean of difference of $d$ population from the whole data pairs, usually 0

$\overline{\mathrm{d}}$ = average of $\mathrm{d}$

$S_{d}=$ standar deviation of $d$

$\mathrm{n}=$ number of paired data

Correlation test between variables. Data were analysed by using the method of Steel \& Torrie (1997).

\section{RESULTS AND DISCUSSION}

\section{Morphometric Parameters of Sheep at Different Growth Rate}

The objective of this study was to predict selection criteria through sheep morphometric parameters in body, head, and tail areas. Male and young sheep were used to get higher growth as the main topic of this work as Villarroel et al. (2008) and Bela \& Haile (2009) reported that male sheep body weight and daily gain were higher $(\mathrm{P}<0.05)$ than female sheep, It might relate to sex hormon influence to growth which include body dimension, fat deposition and muscle as well as bone tissues. Villarroel et al. (2008) also show that younger sheep had higher growth rate than older ones, as the younger sheep (less than $1 \mathrm{yr}$ old) is still in a growth period having quick rate. The daily gain in fast growing sheep at current work $(140.15 \pm 36.41 \mathrm{~g} / \mathrm{head} / \mathrm{d})$ was much higher than previous work (it was $63.38 \pm 3.25 \mathrm{~g} / \mathrm{d} / \mathrm{head}$ as reported by Patel et al. (2004) or $95 \pm 17 \mathrm{~g} / \mathrm{d} /$ head from Duldjaman, 2004). This indicates that grouping of experimental sheep were valid to be used in studying morphometry and carcass between the groups.

Chest circumference, body length and body height were higher in fast growing sheep group (FG) than in slower growing sheep (SG) $(\mathrm{P}<0.05)$ (Table 2). For FG and SG sheep, the values respectively were $61.06 \pm 3.22$ $\mathrm{cm}$ and $56.39 \pm 3.21 \mathrm{~cm}$ for chest circumference, $56.33 \pm 3.61$ $\mathrm{cm}$ and $51.61 \pm 2.38 \mathrm{~cm}$ for body length, and $55.67 \pm 3.27$ $\mathrm{cm}$ and $50.61 \pm 1.95 \mathrm{~cm}$ for body height. On the contrary, chest depth and tail length were not significantly different between the two sheep groups. These results may indicate that chest circumference, body length and body height can be considered to become selection criteria for sheep growth rate, but it was not the case for the chest depth or tail length.

The current findings are similar to that found by Afolayan et al. (2006) who reported that on Yankasa sheep, body weight had very high correlation $(\mathrm{P}<0.001)$ with body morphometry, especially in body height, body length, and chest circumference. This might relate to chest width indicating volume and capacity of the sheep, so sheep with high chest width would have bigger body weight. Fourie (2002); Otoikhian et al. (2008) and Cam et al. (2010), also mentioned that correlation was even higher than the correlation between body length and body weight.

Possible selection criteria were also studied on mouth area (head length, muzzle, top neck and bottom neck circumferences). Head length, muzzle, top neck and bottom neck circumferences were also significantly higher in fast growing than in slow growing sheep $(\mathrm{P}<0.05)$ (Table 3$)$. However, neck length was similar between the two sheep groups. This also may indicate that the head morphometric parameters can be used for selection criterion to select good sheep in their growth rate, except the neck length. This means that selection

Table 2. Average body morphometric on fast growing and slow growing sheep $(\mathrm{cm})$

\begin{tabular}{lcc}
\hline \multirow{2}{*}{ Parameter } & \multicolumn{2}{c}{ Group of sheep } \\
\cline { 2 - 3 } & Fast growing & Slow growing \\
\hline Chest circumference & $61.06 \pm 3.22^{\mathrm{a}}$ & $56.39 \pm 3.21^{\mathrm{b}}$ \\
Body length & $56.33 \pm 3.61^{\mathrm{a}}$ & $51.61 \pm 2.38^{\mathrm{b}}$ \\
Body height & $55.67 \pm 3.27^{\mathrm{a}}$ & $50.61 \pm 1.95^{\mathrm{b}}$ \\
Chest depth & $26.33 \pm 1.97$ & $24.33 \pm 1.63$ \\
Tail length & $21.00 \pm 2.00$ & $20.50 \pm 1.76$ \\
\hline
\end{tabular}

Note: Means in the same row with different superscript differ significantly $(\mathrm{P}<0.05)$. 
sheep on their growth rate can be conducted by judging sheep longer and bigger head, not by longer neck. The bigger head and neck may indicate bigger capacity for feed consumption. This needs further study to confirm this mechanism.

These interesting findings were also supported by another approach using correlation analysis between the morphometric parameters with the body weight and ADG (Table 4). It shows that all parameters were significantly correlated with body weight and ADG $(P<0.05)$, except for tail length and neck length which were not

Table 3. Average head area morphometric on fast growing and slow growing sheep $(\mathrm{cm})$

\begin{tabular}{lcc}
\hline \multirow{2}{*}{ Parameter } & \multicolumn{2}{c}{ Group of sheep } \\
\cline { 2 - 3 } & Fast growing & Slow growing \\
\hline Head length & $19.33 \pm 0.82^{\mathrm{a}}$ & $18.00 \pm 1.10^{\mathrm{b}}$ \\
Muzzle circumference & $18.67 \pm 0.82^{\mathrm{a}}$ & $16.75 \pm 1.47^{\mathrm{b}}$ \\
Top neck circumference & $25.64 \pm 2.16^{\mathrm{a}}$ & $22.67 \pm 1.37^{\mathrm{b}}$ \\
Bottom neck circumference & $32.67 \pm 2.80^{\mathrm{a}}$ & $29.17 \pm 2.48^{\mathrm{b}}$ \\
Neck length & $20.33 \pm 1.37$ & $19.67 \pm 1.21$ \\
\hline
\end{tabular}

Note: Means in the same row with different superscript differ significantly $(\mathrm{P}<0.05)$.

Table 4. Correlation between some morphometric parameters and body weight or average daily gain (ADG)

\begin{tabular}{lcc}
\hline \multirow{2}{*}{ Parameter } & \multicolumn{2}{c}{ Correlation and P values } \\
\cline { 2 - 3 } & Body weight & ADG \\
\hline Chest circumference & 0.961 & 0.604 \\
Body length & 0.000 & 0.038 \\
Body height & 0.922 & 0.699 \\
Chest depth & 0.000 & 0.011 \\
& 0.926 & 0.574 \\
Tail length & 0.000 & 0.051 \\
Head length & 0.869 & 0.614 \\
& 0.000 & 0.034 \\
Muzzle circumference & 0.170 & -0.094 \\
Top neck circumference & 0.597 & 0.771 \\
Bottom neck circumference & 0.935 & 0.633 \\
Neck length & 0.000 & 0.027 \\
& 0.660 & 0.708 \\
& 0.019 & 0.010 \\
& 0.860 & 0.863 \\
& 0.000 & 0.001 \\
& 0.002 & 0.671 \\
& 0.425 & 0.017 \\
& 0.169 & 0.151 \\
\hline
\end{tabular}

Note: Value at the first line at each parameter is a correlation value, and at second line is the $\mathrm{P}$ values. $\mathrm{P}$ values in bold show significant differences $(\mathrm{P}<0.05)$. significantly correlated ( $\mathrm{P}>0.05)$. This may also indicate that the correlated parameters can become selection criteria for judging better body weight and ADG which are basically also growth rate indicators. This selection technique through visualization and judging sheep physical performances through the morphometric can be recommended for good practice in sheep selection program. The conventional animal breeding program is highly recommended to be implemented, because it is cheaper, simpler and more sustainable. However, potential and advanced animal breeding techniques such as molecular genetics using marker genes for selecting commercial sheep traits (Sumantri et al., 2008; Sutikno et al., 2011) need also to be more investigated, in parallel and proportional way with the conventional animal breeding programs.

\section{Carcass Composition of Sheep at Different Growth Rate}

Selection of sheep to have fast or slow growth rate needs to be continued to investigation of the effect of growth rate on carcass composition to make sure the selection would not have negative impacts to the parameters. The results of carcass study show that carcass percentages sheep were not significantly different between sheep groups $(\mathrm{P}>0.05)$ (Table 5). Carcass percentage of FG and SG sheep were respectively, 36.2 $\pm 0.9 \%$ and $35.3 \pm 0.4 \%$. Similarly the different carcass weight was not significant between the two groups of sheep $(6685 \pm 943 \mathrm{~g}$ and $4945 \pm 645 \mathrm{~g})(\mathrm{P}>0.05)$, although the carcass weight difference was actually large, it was close to significant level $(p=0.078)$. The standard deviation was also large, making non-significant level between the two groups. Previous work reported that carcass weight and percentage of slow growing sheep were also lower than in the fast growing sheep (Thatcher \& Gaunt, 1992). Different breed of sheep might cause different response on sheep growth. Small number of experimental animals in current study could be a factor causing similar carcass weight between the sheep groups.

In terms of meat, bones and fat percentages on half carcass, they were also not significantly different between the sheep groups ( $>0.05)$ (Table 5). Average weight of meat, bone, and fat were $1,834 \pm 516 ; 205.8 \pm 56.8$; and $801.6 \pm 122.7 \mathrm{~g}$, while their percentage were $62.5 \pm$ $1.8 \% ; 27.2 \pm 2.0 \%$; and $6.9 \pm 1.5 \%$, respectively. On the contrary, Spedding (1976) found that sheep with fast growth rate were reported to have higher fat tissues in carcass, as fast growth rate sheep had more efficient feed conversion, therefore it cause higher energy input than required, so fat deposition occurred.

These findings indicate that sheep with different rate of growth would produce similar carcass weight, as well as its percentage, unexpected results. However, this is possibly good for the case of sheep having small or slow growth rate, they could produce similar carcass percentage, although the carcass weight tends to be less than in faster growth rate group. It is therefore, sheep with small body weight and growth rate might be still recommended to develop as they can still produce reasonable good carcass production and composition 
Table 5. Carcass percentage and its composition of sheep at different growth rate

\begin{tabular}{|c|c|c|c|c|}
\hline \multirow{2}{*}{ Parameter } & & \multicolumn{2}{|c|}{ Group of sheep } & \multirow{2}{*}{ Mean \pm Sd } \\
\hline & & Fast growing & Slow growing & \\
\hline \multirow{2}{*}{ Carcass } & (g) & $6,685.0 \pm 943.0$ & $4,945.0 \pm 645.0$ & $5,815.0 \pm 794.0$ \\
\hline & $(\%)$ & $36.2 \pm \quad 0.9$ & $35.3 \pm \quad 0.4$ & $35.7 \pm \quad 0.7$ \\
\hline \multirow{2}{*}{ Half carcass } & (g) & $3,421.0 \pm 572.0$ & $2,445.0 \pm 238.0$ & $2,933.0 \pm 405.0$ \\
\hline & $(\%)$ & $38.4 \pm \quad 1.1$ & $37.5 \pm \quad 1.0$ & $38.0 \pm \quad 1.1$ \\
\hline \multirow{2}{*}{ Meat of $1 / 2$ carcass } & (g) & $2,131.0 \pm 317.0$ & $1,537.0 \pm 199.0$ & $1,834.0 \pm 516.0$ \\
\hline & $(\%)$ & $62.4 \pm \quad 1.2$ & $62.7 \pm \quad 2.3$ & $62.5 \pm \quad 1.8$ \\
\hline \multirow{2}{*}{ Bone of $1 / 2$ carcass } & (g) & $250.2 \pm 62.4$ & $161.1 \pm 51.3$ & $205.8 \pm 56.8$ \\
\hline & $(\%)$ & $27.3 \pm \quad 2.14$ & $27.0 \pm \quad 1.9$ & $27.2 \pm \quad 2.0$ \\
\hline \multirow{2}{*}{ Fat of $1 / 2$ carcass } & (g) & $944.0 \pm 220.0$ & $659.2 \pm 25.4$ & $801.6 \pm 122.7$ \\
\hline & $(\%)$ & $7.3 \pm \quad 1.1$ & $6.6 \pm \quad 1.9$ & $6.9 \pm \quad 1.5$ \\
\hline
\end{tabular}

to become a profitable business. Moreover, selection on fast growing sheep could also be further developed, as it would not increase carcass fat percentage, as expected in the selection program.

\section{CONCLUSION}

Selection of fast growing sheep can be recommended as this can be applied easily by using some morphometric parameters and the selection would not also negatively affect weight and percentage of carcass composition.

\section{ACKNOWLEDGEMENT}

The authors would like to acknowledge to LPPM Bogor Agricultural University for facilitating funding this research via a competitive grant project (Hibah Bersaing). Appreciations are also presented to Jastru Manager (to the late Mr. A. Djamil Hasjmi, MS) for his significant cooperation during this work at sheep field lab at Jastru, Jonggol.

\section{REFERENCES}

Afolayan, R. A., I. A. Adeyinka, \& C. A. M. Lakpini. 2006. The estimation of live weight from body measurements in Yankasa sheep. Czech J. Anim. Sci. 51: 343-348.

Bela, B. \& A. Haile. 2009. Factors affecting growth performance of sheep under village management conditions in the south western part of Ethiopia. Livest. Res. for Rur. Dev. 21:11.

Cam, M. A., M. Olfaz, \& E. Soydan. 2010. Possibilities of using morphometrics characteristics as a tool for body weight prediction in Turkish Hair Goats (Kilkeci). Asian J. Anim. and Vet. Adv. 5:52-59.
Duldjaman, M. 2004. Penggunaan ampas tahu untuk meningkatkan gizi pakan domba lokal. Med. Pet. 27:107-110.

Fourie, P. J., F. W. C. Neser, J. J. Olivier, \& C. Van Der Westhuizen. 2002. Relationship between production performance, visual appraisal and body measurements of young Dorper rams. South Afr. J. Animal Sci 32: 256-262.

Noor, R. R. 2008. Genetika Ternak. Cetakan Keempat. Penebar Swadaya, Jakarta.

Otoikhian, C. S. O., A. M. Otoikhian, O. P. Akporhuarho, \& C. Isidahomen. 2008. Correlation of body weight and some body measurement parameters in Ouda sheep under extensive management system. Afr. J. Gen. Agric. 4: 129-133.

Patel, K. M., K. S. Patel, K. N. Wadhwani, S. Parnerkar, P. R. Pandya, \& A. M. Patel. 2004. Comparative growth performance of weaner lambs on non-conventional based ration under intensive production system. Int. J. Agri. Biol. 6:5.

Romans, R. J. \& P. T. Ziegler. 1977. The meat We Eat. $10^{\text {th }}$ Ed. The Interstate Printers and Publishers. Inc., Danville.

Spedding, C. R. W. 1976. Sheep production and grazing management. $2^{\text {nd }}$ Ed. Bailliere, Tindal and Cassel, London.

Steel, R. G., J. H. Torrie, \& D. A. Dickey. 1997. Principle and Procedures of Statistics a Biomedical Approach. 3rd Edit. McGraw - Hill, Inc., Singapore.

Sumantri, C., A. Farajallah, U. Fauzi, \& J. F. Salamena. 2008. Keragaman genetik DNA mikrosatelit dan hubungannya dengan performa bobot badan pada domba lokal. Med. Pet. 31:1-13.

Sutikno, M. Yamin, \& C. Sumantri. 2011. Association of polymorphisms calpastatin gene with body weight of local sheep in Jonggol, Indonesia. Med. Pet. 34:1-6.

Tatcher, L. P. \& G. M. Gaunt. 1992. Effects of growth path and post slaughter chilling regime on carcass composition and meat quality of ewe lambs. Aust. J. Agric. Res. 43: 819-830.

Villarroel, A. B. S., M. B. Maciel, \& M. N. de Oliviera. 2008. Effect of weaning age on lamb growth rate of morada nova breed raised in a tropical extensive production system. Ciencia rural, Santa Maria. 38: 784-788. 